\title{
PERANCANGAN SISTEM PENDATAAN INVENTORI ASET JARINGAN FIBER OPTIK PADA PT. MNC KABEL MEDIACOM
}

\author{
Dedi Setiadi $^{1}$ \\ Fakultas Komputer, \\ Universitas MH. Thamrin, \\ e-mail: \\ $\underline{\text { ranggalawededi@gmail.com }}$
}

\author{
Asep Mursid ${ }^{2}$ \\ Fakultas Komputer, \\ Universitas MH. Thamrin, \\ e-mail: \\ asepmursid2@gmail.com
}

\author{
Tata Sutabri $^{3}$ \\ Fakultas Komputer, \\ Universitas MH. Thamrin, \\ e-mail: \\ tata.sutabri@gmail.com
}

\begin{abstract}
Abstrak
Pelaporan aset dalam internal perusahaan merupakan salah satu informasi terpenting sebagai dasar utama dalam pengambilan keputusan bisnis. Mengendalikan aset yang tepat bukanlan hal yang mudah. Apabila jumlah aset terlalu besar mengakibatkan timbulnya dana yang dikeluarkan terlalu besar, meningkatnya biaya penyimpanan dan resiko kerusakan yang lebih besar. System Development Life Cycle atau Sistem Siklus Hidup Pengembangan Sistem merupakan metode yang digunakan dalam pembahasan ini. Tahapan-tahapan yang dilakukan yaitu: Perencanaan, Analisis, Perancangan, Implementasi, Uji Coba, dan Pengelolaan. Untuk memperoleh informasi yang diperlukan, maka digunakanlah metode observasi, metode wawancara, sera metode kepustakaan. Hasil yang ditemukan pada pengumpulan data diantaranya: banyaknya
\end{abstract}

\section{PENDAHULUAN}

Pelaporan aset dalam internal perusahaan merupakan salah satu informasi terpenting sebagai dasar utama dalam pengambilan keputusan bisnis. Adanya kemajuan teknologi informasi memungkinkan penyajian, pencarian dan pengecekan data internal perusahaan selalu siap kapanpun dibutuhkan. Pencatatan dan usaha pengelolaan aset harus bisa dilakukan dengan sangat cermat dan lebih teliti. Dengan adanya suatu aplikasi yang dapat digunakan secara mobile diharapkan mampu mengurangi penggunaan kertas dalam pencatatan aset lapangan, mempermudah pengaturan aktivitas penggunaan barang dan mempersingkat waktu dalam hal penghitungan jumlah aset yang tersedia. Dan mengutamakan validasi data karena sangat berpengaruh pada kemajuan nilai perusahaan terhadap aset yang dimiliki. Manfaat dari penelitian ini yaitu mendapatkan jumlah material-material terpasang sesuai kondisi implementasi jaringan lapangan yang menjadi target duplikasi data yang mengakibatkan rendahnya tingkat ke akurasian saat data disandingkan dengan data departemen lain. Hal lain yang juga ditemukan adalah kebutuhan waktu yang lama dalam hal pencatatan data material terpasang di lapangan. Untuk menjawab permasalahan di atas, maka dibuatlah suatu sistem aplikasi yang diberi nama Project Control. Tujuan utamanya mampu mengurangi penggunaan kertas, mempersingkat waktu setelah pelaksanaan audit dilakukan, memudahkan pengawasan proyek yang sedang berjalan. Serta aplikasi yang dibuat mampu menampilkan: Informasi Area, Informasi Vendor, Informasi Progress Dokumen hasil Pekerjaan Lapangan, Informasi Jumlah Material Terpasang.

Kata Kunci : inventori, aset, System Development Life Cycle, android

penjualan skala regional, menerapkan keakurasian dan kecepatan pengambilan data, perusahaan mengetahui area-area yang sudah tercakup jaringan fiber optik, mempermudah mendapatkan informasi area-area yang siap dijual, mampu memonitoring aktivitas persetujuan dokumentasi serah terima pekerjaan dari kontraktor.

\section{KAJIAN LITERATUR DAN PEGEMBANGAN HIPOTESIS (JIKA ADA)}

Terdapat dua kelompok pendekatan di dalam pendefinisian sistem, yaitu kelompok yang menekankan pada prosedur dan kelompok yang menekankan pada elemen atau komponennya. Pendekatan yang menekankan pada prosedur mendefinisikan sistem sebagai suatu jaringan kerja prosedur-prosedur yang saling berhubungan, berkumpul bersama-sama untuk melakukan suatu kegiatan atau untuk menyelesaikan suatu sasaran tertentu. Sedangkan pendekatan sistem yang lebih menekankan pada elemen atau komponen 
mendefisinikan sistem sebagai kumpulan elemen yang berinteraksi untuk mencapai suatu tujuan tertentu (Sutabri, 2017:2). Data adalah catatan atas kumpulan fakta. Data kemudian diolah sehingga dapat diutarakan secara jelas dan tepat sehingga dapat dimengerti oleh orang lain yang tidak langsung mengalaminya sendiri, hal ini dinamakan deskripsi. Pemilahan banyak data sesuai dengan persamaan atau perbedaan yang dikandungnya dinamakan klasifikasi. Data merupakan sesuatu yang belum mempunyai arti bagi penerimanya dan masih memerlukan adanya suatu pengolahan. Data bisa berupa suatu keadaan, gambar, suara, huruf, angka, matematika, bahasa ataupun simbol-simbol lainnya yang bisa kita gunakan sebagai bahan untuk melihat lingkungan, obyek, kejadian ataupun suatu konsep. Menurut A. Gima Sugiama (2013: 173) "Inventarisasi aset adalah serangkaian kegiatan untuk melakukan pendataan, pencatatan, pelaporan hasil pendataan aset, dan mendokumentasikannya, baik aset berwujud maupun aset tidak berwujud pada suatu waktu tertentu. Inventarisasi aset dilakukan untuk mendapatkan data seluruh aset yang dimliki, dikuasai sebuah organisasi perusahaan atau instansi pemerintah. Seluruh aset perlu diinventarisasi baik yang diperoleh berdasarkan beban dana sendiri (investasi), hibah ataupun dari cara lainnya" (Sumber: bpkad.banjarkab.go.id). Bagian Dokumentasi dalam satu waktu bisa memperoleh lebih dari 10 dokumen serah terima pekerjaan dari pelaksana proyek, di mana setiap dokumennya merupakan area-area yang berjauhan antara yang satu dengan lainnya. Hal ini berdampak pada Bagian Auditor, yakni dalam hal pembagian tugas hanya disesuaikan area-area yang saling berdekatan. Setiap tim yang ditugaskan melakukan pendataan hanya mampu maksimal 2 area RW dalam waktu satu hari. Pelaporan hasil pendataan material yang terpasang harus menggunakan komputer kantor, sedangkan untuk mencapai target pendataan area-area yang berjauhan tim auditor harus menyiasati keberangkatan dari rumah langsung menuju lokasi pendataan setiap harinya. Sehingga berdampak pada Bagian Dokumentasi yang tidak dapat melakukan proses persetujuan dokumen karena harus memverifikasi antara laporan yang tercatat di dokumen dengan hasil pendataan lapangan tim auditor. Pendataan juga masih menggunakan kertas berupa checklist yang bisa menghambat pergerakan tim auditor lapangan ketika material terpasang menempel di bagian atas tiang penyangga. Faktor lain seperti cuaca juga terkadang menjadi penghambat, karena mengakibatkan kertas basah dan catatan di dalamnya hilang. Human error juga bisa saja terjadi jika dalam satu hari area-area yang didata merupakan area yang sangat luas dalam setiap RW nya dan material yang ditemukan begitu kompleks sehingga karena faktor kelelahan catatan yang dibuat di kertas tertinggal atau bahkan hilang. Android (Safaat H., 2015) adalah "sebuah sistem operasi untuk perangkat mobile berbasis linux yang mencakup sistem operasi, middleware dan aplikasi”. Android menyediakan platform terbuka bagi para pengembang untuk menciptakan aplikasi mereka. Struktur Aplikasi Android atau Fundamental Aplikasi ditulis dalam bahasa pemrograman Java. Kode Java dikompilasi bersama resource file yang dibutuhkan oleh aplikasi. Prosesnya di-package oleh tools yang dinamakan "apt tools" ke dalam paket Android, sehingga menghasilkan file berektensi apk. File apk ini yang disebut dengan aplikasi dan nantinya, dapat dijalankan pada peralatan mobile (device mobile). Pengumpulan data atau informasi yang diperoleh dari pihak-pihak terkait dihimpun dengan: 1) Metode observasi yaitu pengamatan langsung kegiatan yang sedang dilakukan petugas lapangan dalam melakukan pendataan material-material yang terbangun pada jaringan fiber optik. 2) Metode wawancara atau tanya jawab dilakukan secara langsung dengan pihak terkait yaitu petugas lapangan, Kepala Departement maupun Kepala Divisi untuk membentuk input dan output dari hasil pelaporan yang diinginkan. 3) Metode kepustakaan merupakan pengumpulan data dari hasil laporan serah terima pekerjaan yang dilakukan pelaksana proyek yang divalidasi dari hasil pengamatan serta pencatatan langsung oleh masing-masing petugas sesuai kondisi lapangan. Adapun kebutuhan alat dan bahan untuk melakukan pembuatan aplikasi ini antara lain: 1) Peranti Lunak (software): Android SDK (Software Development Kit), Android Studio, Notepad 
++, PHP, MySQL, XAMPP, Sistem Operasi Minimal Windows 7, RAM 2 GB. 2) Peranti Keras (Hardware): laptop Min RAM 2GB, smartphone dengan sistem Android, jaringan wifi atau LAN. Analisis sistem merupakan langkah awal dalam merancang sebuah aplikasi. Tujuan dilakukannya analisis ini yaitu untuk memperoleh kebutuhan apa saja yang diperlukan dalam membangun sebuah aplikasi. Selain itu juga diharapkan mampu mengidentifikasi masalah yang akan ditimbulkan dalam membangun sebuah aplikasi. Analisa sumber daya manusia yang berperan dalam pengadaan dan penggunaan aplikasi ini adalah: 1) Programmer yaitu pembuat aplikasi sistem pendataan inventaris aset. 2) User yaitu pengguna aplikasi yang melakukan pendataan di lapangan maupun yang menganalisa di kantor. 3) Administrator yaitu pengelola aplikasi. Kecepatan dalam mendapatkan informasi data lapangan merupakan faktor utama dalam pembuatan aplikasi ini. Faktor lain yang tidak kalah penting antara lain, keakuratan data dan meminimalisir kehilangan data juga sangat dibutuhkan. Data-data yang akan ditampilkan besumber dari kebutuhan pengguna, mengenai field apa saja yang ingin ditampilkan antara lain: 1) Data informasi area, 2) Data pengguna di tiap regional, 3) Data Material, 4) Data pengawasan proses approval Dokumen vendor.

\section{HASIL DAN PEMBAHASAN}

Unified Modeling Language yang akan dibahas meliputi: Use Case Diagram, Activity Diagram, Class Diagram, dan Sequence Diagram. Use Case Diagram mendeskripsikan sebuah interaksi antara satu atau lebih aktor dengan sistem informasi yang akan dibuat.

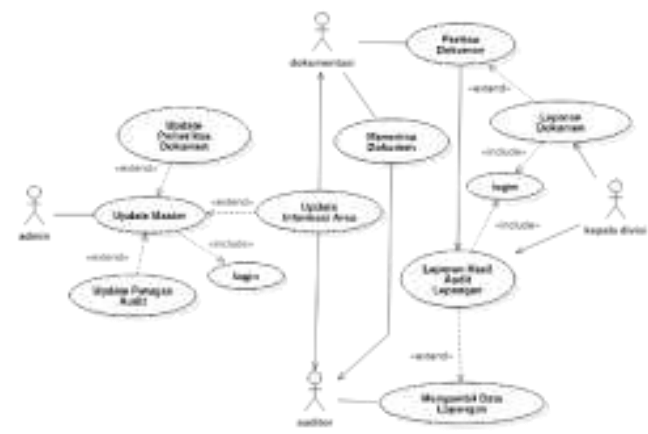

Gambar 4.1 Use Case Diagram
Activity Diagram menggambarkan aliran kerja (work flow) atau aktivitas dari sebuah sistem.

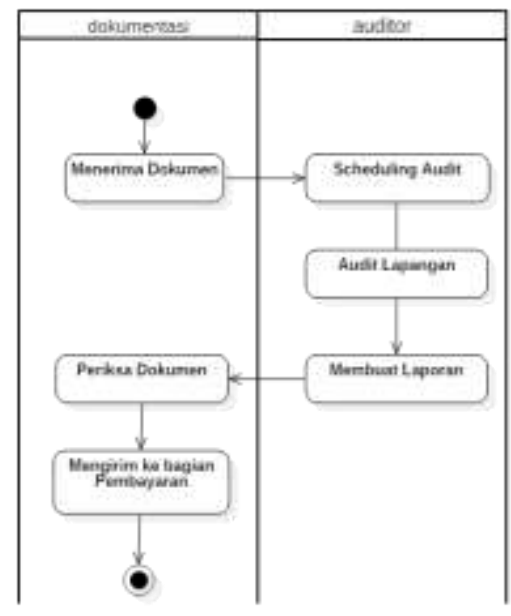

Gambar 4.2 Activity Diagram

Class Diagram adalah model statis yang menggambarkan struktur dan deskripsi class serta hubungannya antara class.

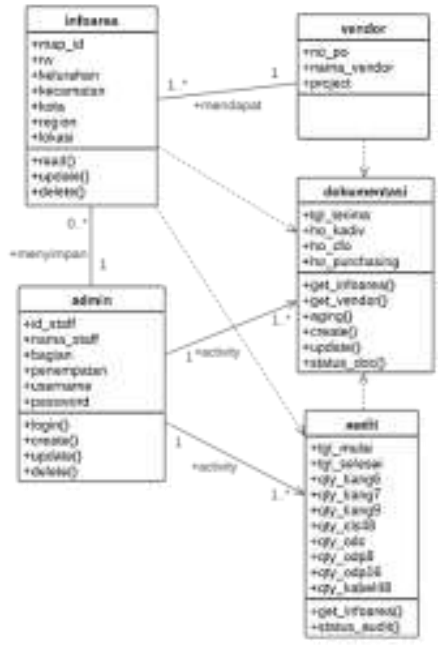

Gambar 4.3 Class Diagram

Interaksi pada Sequence Diagram berdasarkan aktor yang digunakan sebagai berikut:

1) User sebelum login.

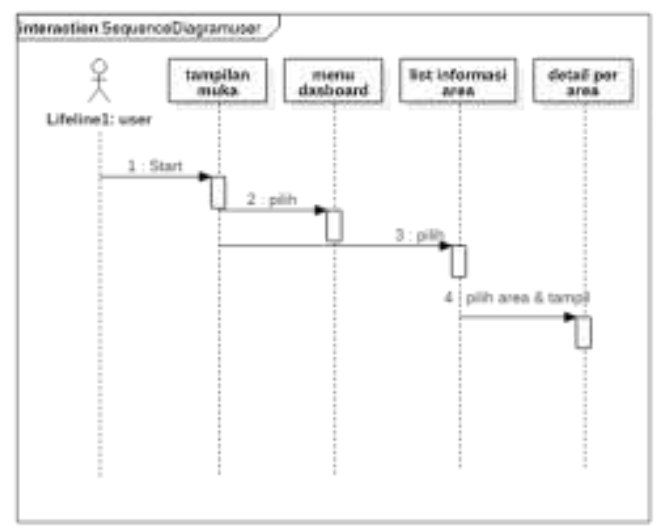

Gambar 4.4 Sequence Diagram User 
2) Admin setelah berhasil login.

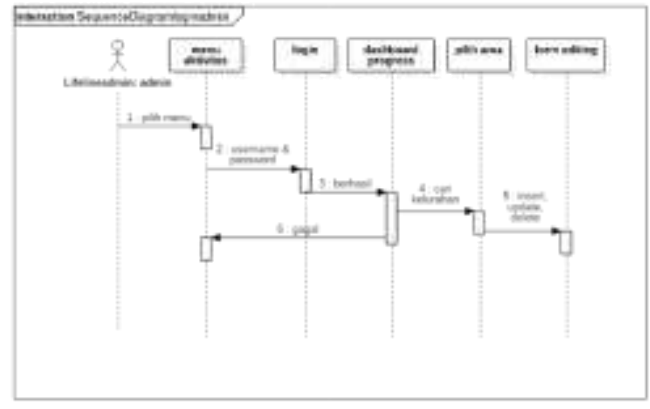

Gambar 4.4 Sequence Diagram Admin

Bentuk Normalisasi Ketiga (3NF)

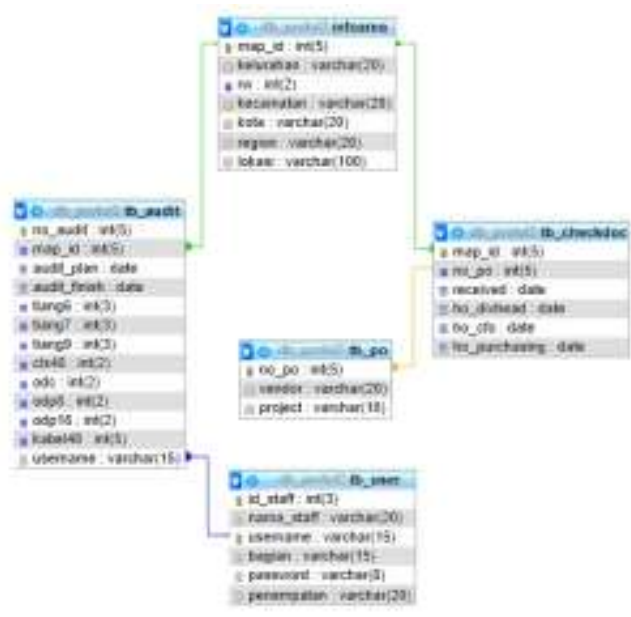

Gambar 4.5 Bentuk Normalisasi Ketiga (3NF)

Bentuk spesifikasi file yang terdapat pada sistem ini memerlukan beberapa file database yang berfungsi untuk menampung data ke dalam bentuk yang lebih teratur dan aman dari kerusakan file yang ada.

\section{1) File Pengguna}

Tabel 4.1 Spesifikasi File Pengguna

\begin{tabular}{|c|c|c|c|c|c|}
\hline No & Nama & Nama Field & Tipe & Panjang & Keterangat \\
\hline 1 & ID Staff & id staff & impge & 3 & primain kyy \\
\hline 2 & Nama & numa_staff & wanchar & 20 & \\
\hline 3 & Nama Peneguna & sempere & wurchar & 15 & \\
\hline 4 & Bagian & bugian & wimhat & 15 & \\
\hline 5 & Sendi & passonond & narchar & 8 & \\
\hline 6 & Wilayah & ponauputave & wirchur & 20 & \\
\hline
\end{tabular}

\section{2) File Area}

Tabel 4.2 Spesifikasi File Area

\begin{tabular}{|c|c|c|c|c|c|}
\hline No. & Nama & Nama Field & Tipe & Panjang & Keterangan \\
\hline 1 & ID Lokasi & map is & butrger & 5 & primeg kor \\
\hline 2 & Kelurahan & kelusahun & wuntwer & 20 & \\
\hline 3 & RW & $\mathrm{rw}$ & integr & 2 & \\
\hline 4 & Kecamatent & kecamatan & warefour & 20 & \\
\hline 5 & Kota & boca & warchar & 20 & \\
\hline 6 & Wilayah & ngiaw & warchart & 20 & \\
\hline 7 & Lakasi & lokasi & marcfast & 100 & \\
\hline
\end{tabular}

\section{3) File Cek Dokumen}

Tabel 4.3 Spesifikasi File Cek Dokumen

\begin{tabular}{|c|c|c|c|c|c|}
\hline No. & Nama & Nama Fideld & Tipe & Panjang & Keterang제 \\
\hline 1 & 1D Lakasi & map id & inthyr & 5 & Primser 6 by \\
\hline 2 & Nomor PO & no 10 & $\operatorname{ing} y=$ & 5 & fordige ing. \\
\hline 3 & Tanponl terima & motionf & dow & 11 & \\
\hline 4 & $\begin{array}{l}\text { Tanpeal Aysurnaf } \\
\text { Kusula Divisi }\end{array}$ & ho_dutheod & dite & 11 & \\
\hline 5 & $\begin{array}{l}\text { Tangal Aprownif } \\
\text { Dirriaur Finance }\end{array}$ & ho_cfo & dist & 11 & \\
\hline 6 & $\begin{array}{l}\text { Tanegal } \\
\text { diverahkan ke } \\
\text { Purchating }\end{array}$ & bo punthoseg & dere & 11 & \\
\hline
\end{tabular}

\section{4) File Audit}

Tabel 4.4 Spesifikasi File Audit

\begin{tabular}{|c|c|c|c|c|c|}
\hline No & Nama & $\begin{array}{l}\text { Nama } \\
\text { Fincle }\end{array}$ & Tipe & Panjang & Keterangaa \\
\hline 1 & Nomor Audit & Do wodie & intgror & 5 & eminary ky \\
\hline 2 & ID Lokani & $\operatorname{map}$ ia & insogr & 5 & freclige iny \\
\hline 3 & Tuejeal Retcana Autit & audit nier & $d a$ & 11 & \\
\hline 4 & Treggat Selrsai Audit & andit finst & dive & 11 & \\
\hline 5 & Quneciny Tiang foin & tiange & atsper & 3 & \\
\hline 6 & Cunotity Tiang ?m & tiang? & intopgr & 3 & \\
\hline 7 & Quantity Tiane fim & tiane? & inesog & 3 & \\
\hline 3 & Onandiry Cooute 48 & clets & augagr & 2 & \\
\hline 9 & Cuverity ODC & adc & ingor & 2 & \\
\hline 10 & Quntiry ADP 8 & adpr & inters & 2 & \\
\hline II & Quactity ODP & adpl6 & inger & 2 & \\
\hline 12 & Oadiory Pagiang Kabel & batells & $\operatorname{ins} x \mathrm{x}$ & 5 & \\
\hline 13 & Noma Peingzuns & tosemame & Amikr & 15 & fropoge iny \\
\hline
\end{tabular}

5) File Purchase Order

Tabel 4.5 Spesifikasi File Purchase Order

\begin{tabular}{|c|c|c|c|c|c|}
\hline No & Nama & Nama Fíd & Tipe & Panjang & Keterangain \\
\hline 1 & Nomor $P O$ & no_po & ather & 5 & primer for \\
\hline 2 & Nama Vendor & voudor & nanctar & 20 & \\
\hline 3 & Project & project & warchar & 10 & \\
\hline
\end{tabular}

Tampilan input terdiri dari:

1) Menu 


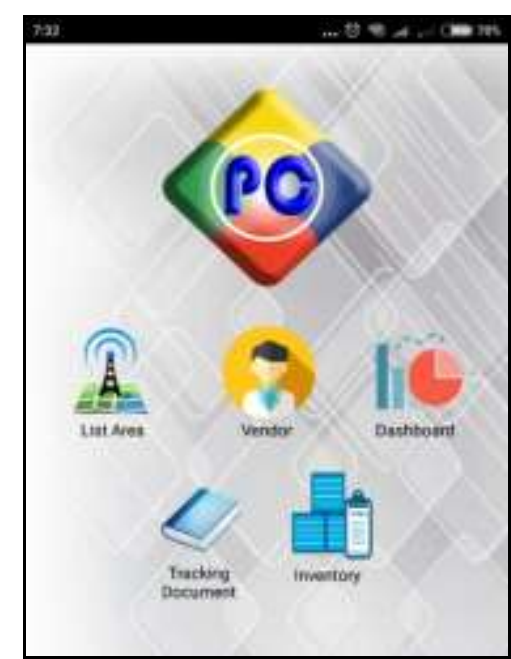

Tabel 4.6 Gambar Tampilan Menu

2) Login

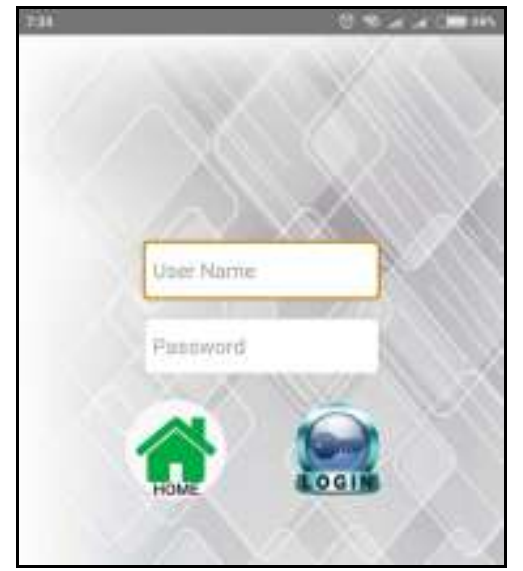

Tabel 4.7 Gambar Tampilan Login

3) Data Pengguna

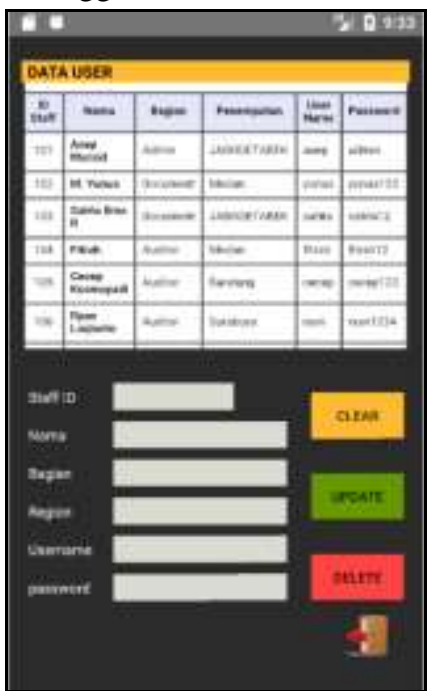

Tabel 4.8 Gambar Tampilan Data Pengguna

4) Input Data Area

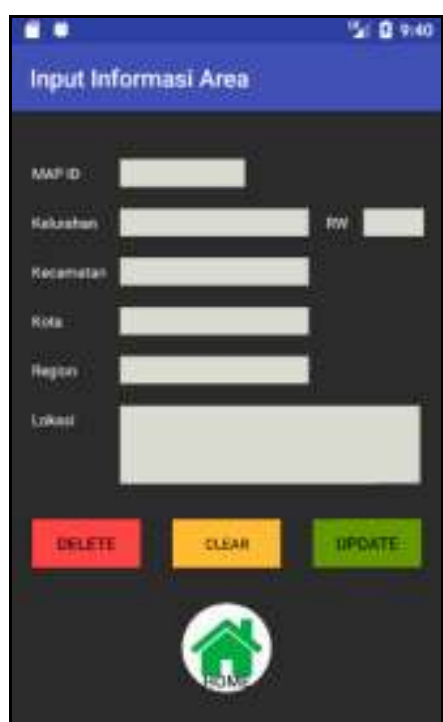

Tabel 4.9 Gambar Tampilan Data Area

5) Input Pemeriksaan Dokumen

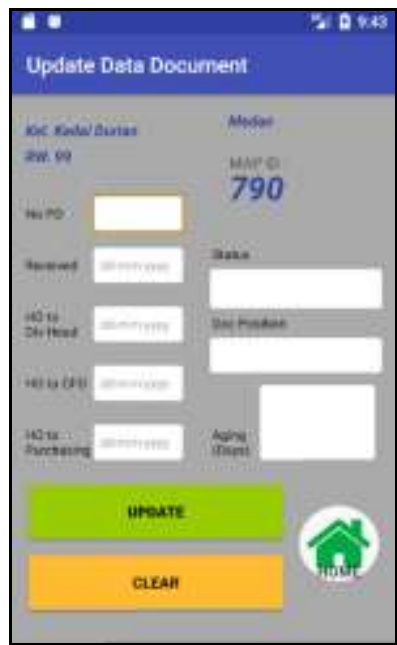

Tabel 4.10 Gambar Tampilan Pemeriksaan Dokumen

6) Input Purchase Order

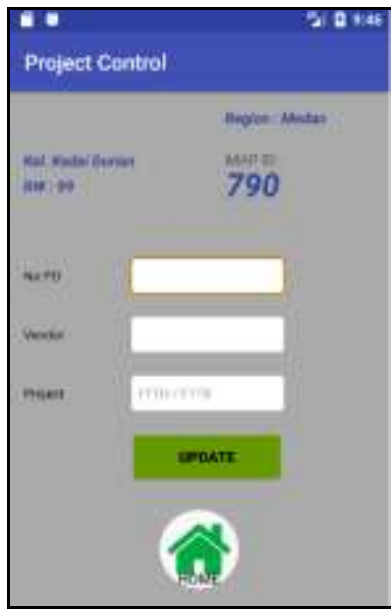

Tabel 4.11 Gambar Tampilan Input Purchase order 
7) Input Data Audit

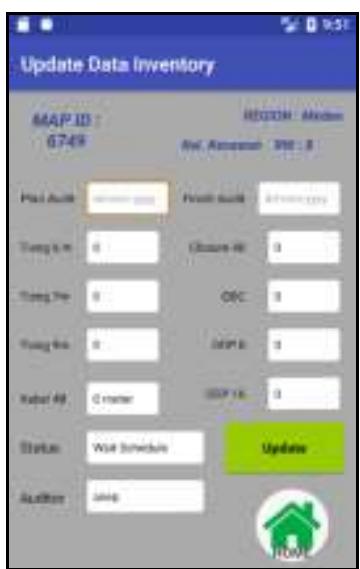

Tabel 4.11 Gambar Tampilan Input Data Audit

Tampilan Output:

1) Pencarian Data Area

\begin{tabular}{|c|c|c|c|}
\hline \multicolumn{2}{|c|}{0} & \multicolumn{2}{|r|}{90 Gate } \\
\hline \multicolumn{2}{|c|}{ Cari Kelurahan } & & Q \\
\hline$m$ & Opoonet: & & Mag it is 342 \\
\hline nom & 7. & निоран & Baviong \\
\hline net. & Tamanc Uas & & Meeris an \\
\hline EN & 7 & Frpail & semarno \\
\hline nd. & Soctaiduran & & Mo id 720 \\
\hline DW & 9 & मиран & Uedn \\
\hline nere & To Hartos & & Now ite any \\
\hline ww & 4 & Hiosh & Nints \\
\hline ves & mons & & Moin $\% 6$ \\
\hline niv & 17 & Hagan & vedn \\
\hline nof & mon & & Meer in 924 \\
\hline$w w$ & 73 & Hegin & tron \\
\hline
\end{tabular}

Tabel 4.12 Gambar Tampilan Data Area

2) Informasi Detail Area

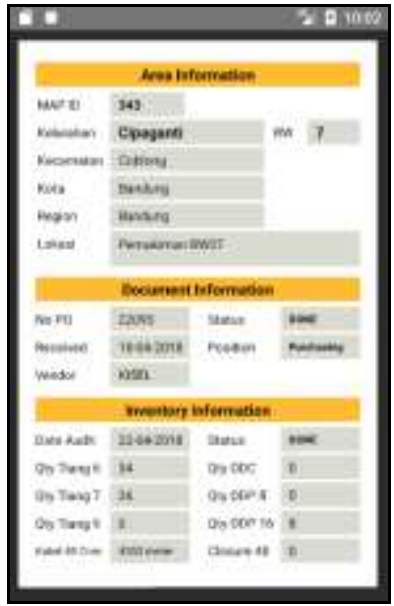

Tabel 4.13 Gambar Tampilan Informasi Detail Area

3) Dashboard

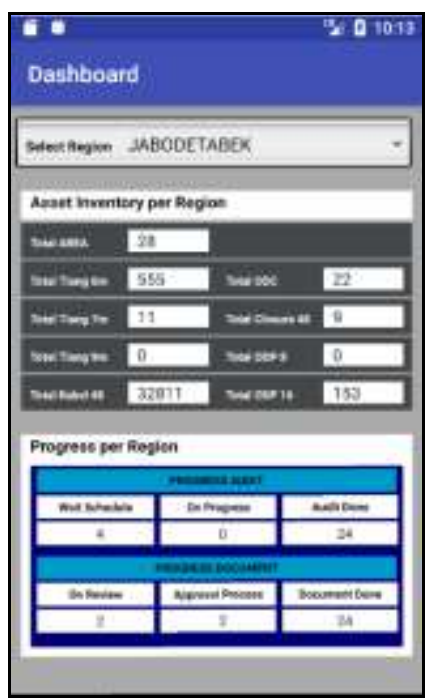

Tabel 4.14 Gambar Tampilan Dashboard

\section{KESIMPULAN}

Berkembangnya dunia teknologi terutama dalam sistem informasi seolah memaksa dunia bisnis untuk menyajikan data perusahaan dengan cepat dan akurat. Dengan adanya sistem informasi berbasis android pada pembahasan bab sebelumnya, diharapkan mampu menyajikan laporan yang dapat dilihat tidak hanya di ruangan kantor tetapi juga dapat dilihat dari mana saja. Informasi yang ditampilkan pada aplikasi ini antara lain: 1) Informasi Area, 2) Informasi Vendor (Pelaksana Proyek), 3) Informasi Progres Laporan Pekerjaan Vendor, 4) Informasi Inventori Aset Lapangan, 5) Dashboard yang menjadi bagian monitoring pelaksanaan proyek baik dokumentasi maupun hasil implementasi.

\section{REFERENSI}

Imam, A. (2015). Pengertian dan Perbedaan Data dan Informasi. Retrieved from http://www.kuliah.info/2015/05/pengertian -dan-perbedaan-data-dan.html

Kabupaten Banjar, B. (2017). Inventarisasi Aset. Retrieved from http://bpkad.banjarkab.go.id/index.php/201 7/03/09/inventarisasi-aset/

Safaat H., N. (2015). In Android Pemrograman Aplikasi Mobile Smartphone dan Tablet PC Berbasis Android. Bandung: Informatika

Sutabri, T. (2017). In Analisis Sistem Informasi. Yogyakarta: Andi. 
Sutabri, Tata. (2015). Konsep Sistem Informasi. Andi. Yogyakarta.

Safaat H., Nazruddin. (2015). Android Pemrograman Aplikasi Mobile Smartphone dan Tablet PC Berbasis Android. Informatika. Bandung.

Kabupaten Banjar, BPKAD. (2017). Inventarisasi Aset. [Online]http://bpkad.banjarkab.go.id/index .php/2017/03/09/inventarisasi-aset/; Diakses 10 Juni 2018.
Imam, Aang. (2015). Pengertian dan Perbedaan Data dan Informasi. [Online] http://www.kuliah.info/2015/05/pengertian -dan-perbedaan-data-dan.html; Diakses 10 Juni 2018. 